\title{
Actinoalloteichus cyanogriseus gen. nov., sp. nov.
}

\author{
Tomohiko Tamura, ${ }^{1}$ Liu Zhiheng, ${ }^{2}$ Zhang Yamei $^{2}$ and Kazunori Hatano ${ }^{1}$
}

Author for correspondence: Tomohiko Tamura. Tel: +8166300 6555. Fax: +81663006814. e-mail: k90089@simail.ne.jp

\footnotetext{
1 Institute for Fermentation, Osaka, 2-17-85 Jusohonmachi Yodogawa-ku, Osaka 532-8686, Japan

2 Institute for Microbiology, Chinese Academy of Sciences, Beijing, 100080, PR China
}

\begin{abstract}
Phylogenetic analysis of 'Actinoalloteichus cyanogriseus' based on its $16 \mathrm{~S}$ rDNA sequence confirmed that the organism belongs to the family Pseudonocardiaceae. It contains glutamic acid, alanine and mesodiaminopimelic acid as cell wall amino acids, and menaquinone $\mathbf{9}\left(\mathrm{H}_{4}\right)$. Its taxonomic characteristics differ from those of the previously described organisms of the family Pseudonocardiaceae. On the basis of these morphological, physiological, chemotaxonomic and phylogenetic analyses, a new genus, Actinoalloteichus, is proposed, along with a new species, namely Actinoalloteichus cyanogriseus sp. nov. The type strain is $A$. cyanogriseus IFO $14455^{\top}$ ( = AS 4.1159' $=$ JCM 6095').
\end{abstract}

Keywords: Actinoalloteichus gen. nov., family Pseudonocardiaceae, 16S rRNA

\section{INTRODUCTION}

Liu et al. (1984) described 'Actinoalloteichus cyanogriseus' as a new taxa having the following characteristics: blue-grey aerial mycelium with straight spore chains is present; the aerial and substrate mycelia form septa and fragment after 2 weeks incubation; bluishviolet soluble pigment is produced; the cell wall contains meso-diaminopimelic acid, glycine and lysine and whole-cell hydrolysate contains galactose without other characteristic sugars; the $\mathrm{G}+\mathrm{C}$ content of DNA is $69.54 \mathrm{~mol} \%$.

Itoh et al. (1987) reported the morphological and chemotaxonomic characteristics of this organism and indicated that it contains glutamic acid, alanine and meso-diaminopimelic acid as cell wall amino acids, isoand anteiso-branched fatty acids as the predominant cellular fatty acids, and menaquinone $9\left(\mathrm{H}_{4}\right)$.

Recently, we determined the phylogenetic position of 'Actinoalloteichus cyanogriseus' on the basis of its $16 \mathrm{~S}$ rDNA sequence (Tamura \& Hatano, 1998), showing that it belongs to the family Pseudonocardiaceae (Stackebrandt et al., 1997). We also showed that it represents a line of descent distinct from those of previously described organisms.

In this paper, we describe the characterization and classification of 'A. cyanogriseus' and propose its designation as $A$. cyanogriseus gen. nov., sp. nov.

The DDBJ accession number for the 16S rRNA gene sequence of Actinoalloteichus cyanogriseus IFO $14455^{\top}$ is AB006178.

\section{METHODS}

Micro-organisms and culture conditions. 'A. cyanogriseus' IFO $14455^{\mathrm{T}}$, isolated from a soil sample collected from the Yunnan province of China (Liu et al., 1984), was used. To obtain cells, the organism was grown at $28{ }^{\circ} \mathrm{C}$ for $5 \mathrm{~d}$ in yeast extract/glucose broth (containing $10 \mathrm{~g}$ yeast extract and $10 \mathrm{~g}$ D-glucose in $1000 \mathrm{ml}$ distilled water, $\mathrm{pH} \mathrm{7.0)}$ on a rotary shaker.

The culture grown on HV agar (Hayakawa \& Nonomura, 1987) for $2-3$ weeks at $28^{\circ} \mathrm{C}$ was observed with a light microscope and a scanning electron microscope as described previously (Tamura et al., 1998). Cultural and physiological characteristics were determined as described previously (Yokota et al., 1993; Gordon et al., 1974).

Phylogenetic analysis. The $16 \mathrm{~S}$ rDNA sequences of ' $A$. cyanogriseus' and reference organisms were aligned against that of Streptomyces ambofaciens (Pernodet et al., 1989). The CLUSTAL W version 1.7 software (Thompson et al., 1994) package was used to generate the evolutionary distances (the $K_{\text {nuc }}$ value of Kimura, 1980) and the similarity values and to reconstruct the phylogenetic tree by the neighbour-joining method (Saitou \& Nei, 1987) from $K_{\text {nuc }}$ values. The topology of the phylogenetic tree was evaluated by the bootstrap resampling method of Felsenstein (1985) with 1000 replicates. The NJplot method (Perrière \& Gouy, 1996) was used for plotting the phylogenetic tree.

\section{RESULTS AND DISCUSSION}

Growth characteristics

As shown in Table 1, strain IFO $14455^{\mathrm{T}}$ showed good growth on yeast extract/malt extract agar (ISP medium 2) and oatmeal agar (ISP medium 3) and 
Table 1. Cultural characteristics of Actinoalloteichus cyanogriseus IFO $14455^{T}$

\begin{tabular}{|c|c|}
\hline Medium & Characteristics* \\
\hline \multicolumn{2}{|c|}{ Yeast extract/malt extract agar (ISP-2) } \\
\hline Growth & Good, brownish-grey (118) to light brownish-grey (117) \\
\hline Aerial mycelium & Good, light purplish-grey (127) \\
\hline Reverse colour & Black \\
\hline Soluble pigment & Black \\
\hline \multicolumn{2}{|c|}{ Oatmeal agar (ISP-3) } \\
\hline Growth & Good, yellowish-grey (105) \\
\hline Aerial mycelium & Good, pale blue (96) \\
\hline Reverse colour & Yellowish-grey (105) to olive grey (122) \\
\hline Soluble pigment & Light greyish-red (115) \\
\hline \multicolumn{2}{|c|}{ Inorganic salts/starch agar (ISP-4) } \\
\hline Growth & Poor, colourless \\
\hline Aerial mycelium & Poor, colourless \\
\hline Reverse colour & Colourless \\
\hline \multicolumn{2}{|c|}{ Glycerol/asparagine agar (ISP-5) } \\
\hline Growth & Poor, colourless to light greenish-grey (123) \\
\hline Aerial mycelium & Moderate, light greenish-grey (123) to greyish-white \\
\hline Reverse colour & Light greenish-grey (123) \\
\hline \multicolumn{2}{|c|}{ Peptone/yeast extract/iron agar (ISP-6) } \\
\hline Growth & Moderate, yellowish-grey (105) to dark reddish-brown (104) \\
\hline Aerial mycelium & Poor, white \\
\hline Reverse colour & Moderate yellow (64) to dark reddish-brown (104) \\
\hline Soluble pigment & Black \\
\hline \multicolumn{2}{|c|}{ Tyrosine agar (ISP-7) } \\
\hline Growth & Poor, yellowish-grey (105) \\
\hline Aerial mycelium & Moderate, white \\
\hline Reverse colour & Yellowish-grey (105) \\
\hline \multicolumn{2}{|l|}{ Calcium malate agar } \\
\hline Growth & Poor, colourless \\
\hline Aerial mycelium & Poor, white \\
\hline Reverse colour & Colourless \\
\hline
\end{tabular}

* The colour codes correspond to those in A Mycological Colour Chart (Rayner, 1970).

produced a black soluble pigment on yeast extract/ malt extract agar and peptone/yeast extract/iron agar (ISP medium 6), a light greyish-red pigment on oatmeal agar and a yellowish-grey pigment on tyrosine agar (ISP medium 7). It developed purplish-grey or blue aerial mycelium on yeast extract/malt extract agar, oatmeal agar and glycerol/asparagine agar (ISP medium 5).

\section{Physiological characteristics}

The biochemical properties of strain IFO $14455^{\mathrm{T}}$ are shown in Table 2. The strain utilized D-glucose, maltose, xylose, mannitol, rhamnose, mannose and sorbitol. Decomposition of casein and urea, growth in Sabouraud dextrose broth and MacConkey agar, hydrolysis of aesculin and hippurate, utilization of sodium citrate, sodium succinate and calcium malate, gelatin liquefaction and reduction of nitrate were all negative. It grew at 20 and $37^{\circ} \mathrm{C}$, but could not grow at 15 or $45^{\circ} \mathrm{C}$.

\section{Chemotaxonomic characteristics}

Chemotaxonomic characteristics reported by Itoh et al. (1987) are indicated in Table 3. This organism contains MK-9 $\left(\mathrm{H}_{4}\right)$ as the major menaquinone; glucose, mannose, galactose and rhamnose as the wholecell sugars; and meso-diaminopimelic acid, glutamic acid and alanine as the amino acids in the cell wall. Mycolic acids are absent. The acyl type of the cell wall polysaccharides is acethyl. Phosphatidylethanolamine, phosphatidylinositol and phosphatidylglycerol were detected. The $\mathrm{G}+\mathrm{C}$ content of the DNA is $72.5 \mathrm{~mol} \%$. The major cellular fatty acids are anteiso- $\mathrm{C}_{17: 0}$, iso$\mathrm{C}_{15: 0}$, iso- $\mathrm{C}_{16: 0}$ and anteiso- $\mathrm{C}_{15: 0}$. The cellular fatty acid pattern corresponds to type $2 \mathrm{~d}$ (Kroppenstedt, 1985).

\section{Analysis of $16 \mathrm{~S}$ rDNA sequences}

The phylogenetic tree obtained by applying the neighbour-joining method (Saitou \& Nei, 1987) to $K_{\text {nuc }}$ values of Kimura (1980) is depicted in Fig. 1. 
Table 2. Phenotypic characteristics of $A$. cyanogriseus IFO $14455^{\top}$

\begin{tabular}{|c|c|}
\hline Characteristic & Result \\
\hline \multicolumn{2}{|l|}{ Utilization of:* } \\
\hline Glucose & ++ \\
\hline Maltose & ++ \\
\hline Inositol & - \\
\hline Fructose & - \\
\hline Arabinose & $+/-$ \\
\hline Xylose & + \\
\hline Mannitol & + \\
\hline Rhamnose & ++ \\
\hline Raffinose & - \\
\hline Mannose & + \\
\hline Saccharose & $+/-$ \\
\hline Sorbitol & + \\
\hline Decomposition of casein $\dagger$ & - \\
\hline Decomposition of urea $\uparrow$ & - \\
\hline Growth in Sabouraud dextrose broth $\dagger$ & - \\
\hline Growth on MacConkey agar† & - \\
\hline Hydrolysis of aesculin $\uparrow$ & - \\
\hline Hydrolysis of hippurate $\dagger$ & - \\
\hline Hydrolysis of starch $\dagger$ & $\mathrm{W}$ \\
\hline \multicolumn{2}{|l|}{ Resistance to: $t$} \\
\hline Methyl violet & - \\
\hline Pyronin B & - \\
\hline Survival at $50^{\circ} \mathrm{C} \dagger$ & - \\
\hline \multicolumn{2}{|l|}{ Utilization of : $\dagger$} \\
\hline Sodium citrate & - \\
\hline Sodium oxalate & $\mathrm{W}$ \\
\hline Sodium succinate & - \\
\hline Calcium malate & - \\
\hline Resistance to lysozyme & + \\
\hline Nitrite from nitrate $\dagger$ & - \\
\hline Gelatin liquefaction $\dagger$ & - \\
\hline \multicolumn{2}{|l|}{ Pigmentation in:† } \\
\hline ISP-1 & - \\
\hline ISP-6 & + \\
\hline ISP-7 & - \\
\hline \multicolumn{2}{|l|}{ Growth temperature $\left({ }^{\circ} \mathrm{C}\right) \dagger$} \\
\hline 15 & - \\
\hline 20 & + \\
\hline 25 & + \\
\hline 30 & + \\
\hline 37 & + \\
\hline 45 & - \\
\hline
\end{tabular}

$*++$, Good; + , moderate; $+/-$, poor; - , none.

$\dagger+$, Positive; - , negative; w, weakly positive.

Analysis of the 16S rDNA confirmed that 'A. cyanogriseus' falls into the family Pseudonocardiaceae. However, 'A . cyanogriseus' represents a line of descent distinct from those of previously described organisms. 'A. cyanogriseus' has as its closest neighbours members of the genera Kutzneria (Stackebrandt et al., 1994) and Streptoalloteichus (Tomita et al., 1987). The binary
Table 3. Chemotaxonomic characteristics of A. cyanogriseus IFO $14455^{\top}$

\begin{tabular}{|c|c|}
\hline Characteristic & \\
\hline \multicolumn{2}{|l|}{ Cell wall composition } \\
\hline Glutamic acid & $1 \cdot 0$ \\
\hline Glycine & $<0 \cdot 1$ \\
\hline Alanine & $1 \cdot 7$ \\
\hline $\mathrm{A}_{2} \mathrm{pm}$ & 0.7 \\
\hline Isomer of $\mathrm{A}_{2} \mathrm{pm}$ & meso- $\mathrm{A}_{2} \mathrm{pm}$ \\
\hline Acyl type & Acetyl \\
\hline Sugar composition & $\begin{array}{l}\text { Ribose, mannose, } \\
\text { glucose, galactose }\end{array}$ \\
\hline \multicolumn{2}{|l|}{ Diagnostic phospholipids } \\
\hline Diphosphatidylglycerol & + \\
\hline $\begin{array}{l}\text { Phosphatidylmonomethyl- } \\
\text { ethanolamine }\end{array}$ & + \\
\hline Phosphatidylglycerol & + \\
\hline Phosphatidylinositol & + \\
\hline Phosphatidylinositol mannoside & + \\
\hline Phosphatidylcholine & - \\
\hline \multicolumn{2}{|l|}{ Menaquinone composition (\%) } \\
\hline MK-8 $\left(\mathrm{H}_{4}\right)$ & 10 \\
\hline MK-9 $\left(\mathrm{H}_{2}\right)$ & 9 \\
\hline MK-9 $\left(\mathrm{H}_{4}\right)$ & 75 \\
\hline $\mathrm{MK}-9\left(\mathrm{H}_{6}\right)$ & 2 \\
\hline $\mathrm{MK}-10\left(\mathrm{H}_{4}\right)$ & 3 \\
\hline Mycolic acid & Absent \\
\hline $\mathrm{G}+\mathrm{C}$ content of DNA $(\mathrm{mol} \%)$ & $72 \cdot 5$ \\
\hline \multicolumn{2}{|l|}{ Cellular fatty acid composition (\%) of: } \\
\hline \multicolumn{2}{|l|}{ Anteiso-branched fatty acids } \\
\hline $\mathrm{C}_{15: 0}$ & 10 \\
\hline $\mathrm{C}_{17: 0}$ & 20 \\
\hline \multicolumn{2}{|l|}{ Iso-branched fatty acids } \\
\hline $\mathrm{C}_{14: 0}$ & 5 \\
\hline $\mathrm{C}_{15: 0}$ & 15 \\
\hline $\mathrm{C}_{16: 0}$ & 19 \\
\hline $\mathrm{C}_{16: 1}$ & 8 \\
\hline $\mathrm{C}_{17: 0}$ & 3 \\
\hline \multicolumn{2}{|l|}{ Saturated fatty acids } \\
\hline $\mathrm{C}_{16: 0}$ & 2 \\
\hline $\mathrm{C}_{18: 0}$ & Trace \\
\hline \multicolumn{2}{|l|}{ Unsaturated fatty acid } \\
\hline $\mathrm{C}_{16: 1}$ & 2 \\
\hline Other components & $\mathrm{C}_{15: 0}, \mathrm{C}_{17:} 0$ \\
\hline
\end{tabular}

Data are from Itoh et al. (1987).

similarity value for $16 \mathrm{~S}$ rDNA of ' $A$. cyanogriseus' and Kutzneria viridogrisea is $94.5 \%$, while that for ' $A$. cyanogriseus' and Streptoalloteichus hindus is $95 \cdot 1 \%$.

'A. cyanogriseus' develops aerial mycelium with straight spore chains (Fig. 2) and contains glucose, mannose, galactose and rhamnose as the whole-cell sugars and meso-diaminopimelic acid, glutamic acid and alanine as the cell wall amino acids. Itoh et al. (1987) reported that these morphological and cell wall components correspond to those of the genus 


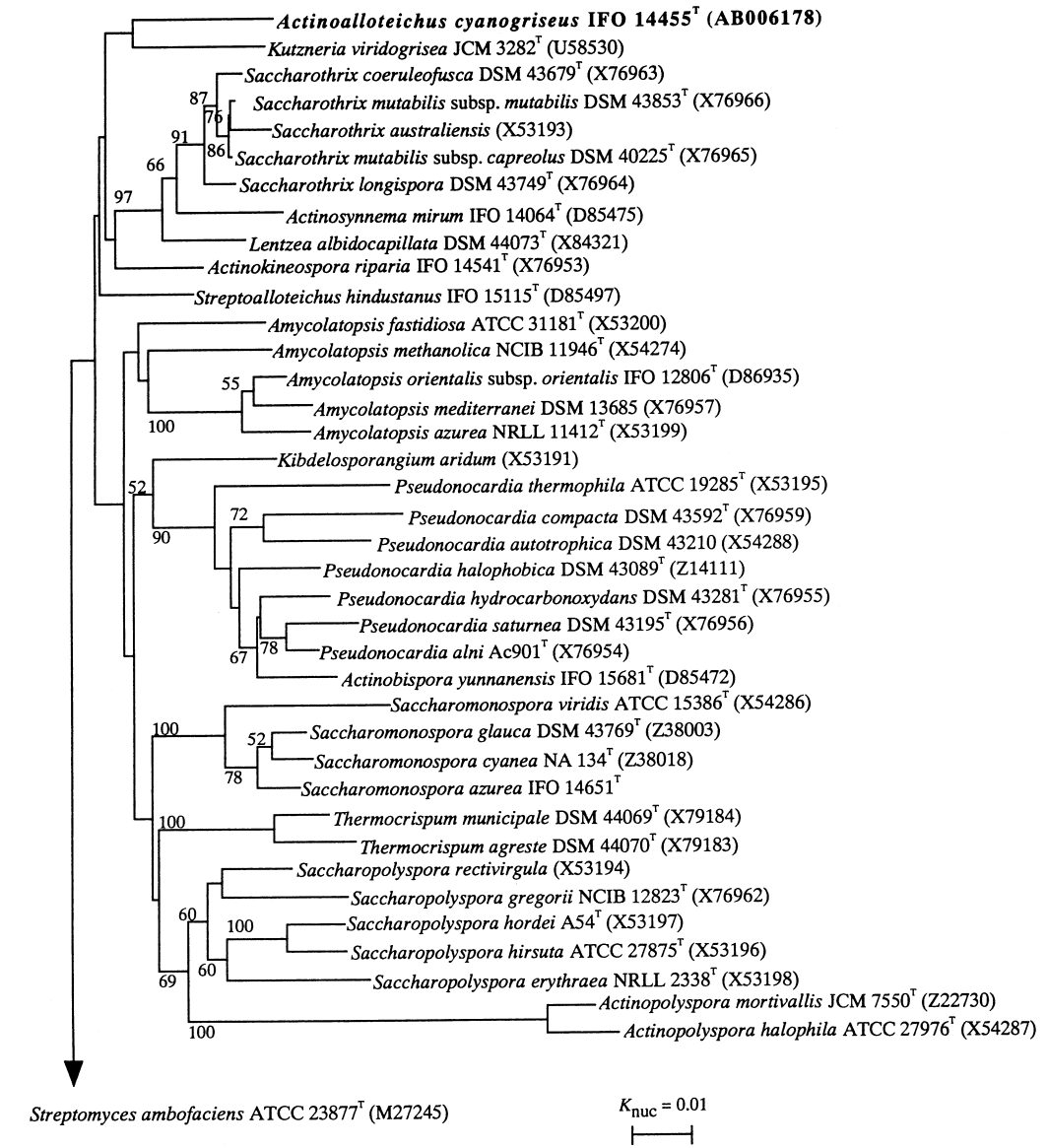

Fig. 1. Phylogenetic tree derived from $16 \mathrm{~S}$ rRNA sequences for the members of the Pseudonocardiaceae. Streptomyces ambofaciens was used as the root organism. Bar, $0.01 K_{\text {nuc }}$ in nucleotide sequences. The numbers on the branches are confidence limits (expressed as percentages) estimated from a bootstrap analysis with 1000 replicates (only percentages above $50 \%$ are indicated).

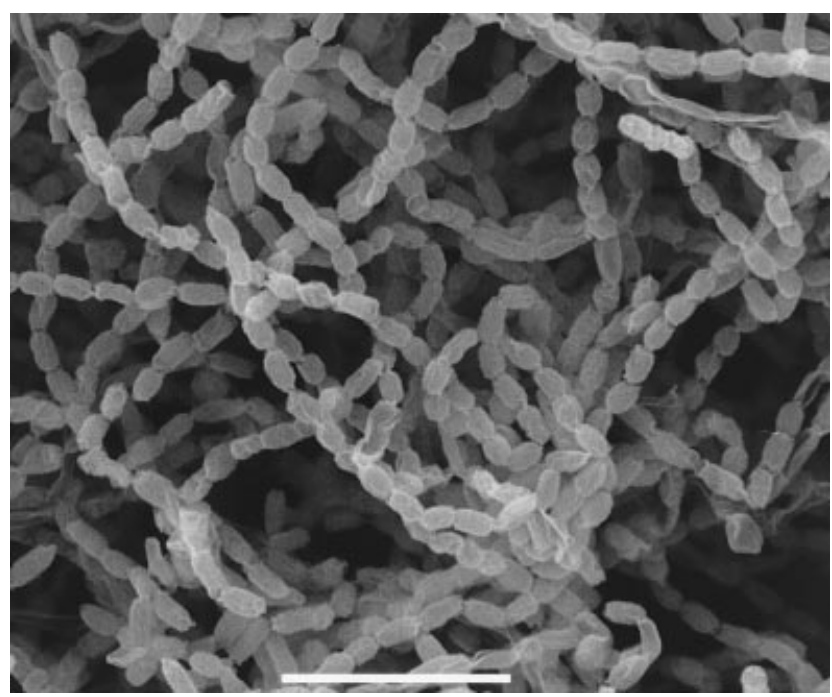

Fig. 2. Scanning electron micrograph of $A$. cyanogriseus IFO $14455^{\top}$ grown on $\mathrm{HV}$ agar for $14 \mathrm{~d}$ at $28^{\circ} \mathrm{C}$. Bar, $5 \mu \mathrm{m}$.

Nocardiopsis. However, phylogenetic analysis indicated that 'A. cyanogriseus' is remote from the genus Nocardiopsis and belongs to the family Pseudonocardiaceae, its closest relation being the genus Streptoalloteichus (Tomita et al., 1987). The taxonomic characteristics of the members of the family Pseudonocardiaceae are shown in Table 4. The genus Streptoalloteichus has fatty acid type $3 \mathrm{e}$ and develops sporangia, while Kutzneria has fatty acid type 3c and develops sporangia. On the other hand, 'A. cyanogriseus' has no 10-methylated fatty acid among the cellular fatty acids (fatty acid type 2d) and develops no sporangia or motile cells. The genera Saccharothrix (Labeda et al., 1984), Actinosynnema (Hasegawa et al., 1978) and Thermocrispum (Korn-Wendisch et al., 1995) have meso-diaminopimelic acid in the cell wall (cell wall type III) and long spore chains. However, the present organism is distinguished from these genera by its morphological characteristics, fatty acid components and non-motility. Thus, in terms of its morphological and chemotaxonomic characteristics, the strain is distinct from known actinomycetes belonging to the family Pseudonocardiaceae (Table 4).

On the basis of morphological, physiological, chemotaxonomic and phylogenetic criteria, 'A. cyanogriseus' is readily distinguishable from the actinomycetes mentioned above and warrants a new taxon. Therefore, we propose that 'A. cyanogriseus' be classified in a new genus, Actinoalloteichus gen. nov., with the type species $A$. cyanogriseus sp. nov. This strain has been deposited in the Institute for Fermentation (Osaka) as strain IFO $14455^{\mathrm{T}}$, in the Institute of Microbiology 
Table 4. Morphological and chemotaxonomic characteristics of Actinoalloteichus and related actinomycete genera

NT, Not tested; ND, not detected.

\begin{tabular}{|c|c|c|c|c|c|c|}
\hline Genus & Morphological characteristics & $\begin{array}{l}\text { Cell wall } \\
\text { type* }^{*}\end{array}$ & $\begin{array}{l}\text { Glycolyl } \\
\text { test }\end{array}$ & Major menaquinone(s) & $\begin{array}{l}\text { Fatty } \\
\text { acid } \\
\text { type } \dagger\end{array}$ & $\begin{array}{c}\text { Whole-cell } \\
\text { sugar } \\
\text { pattern }\end{array}$ \\
\hline Actinoalloteichus & Long spore chain & III & Acetyl & MK-9( $\left(\mathrm{H}_{4}\right), 8\left(\mathrm{H}_{4}\right), 9\left(\mathrm{H}_{2}\right)$ & $2 d$ & $\mathrm{C}$ \\
\hline Lentzea & $\begin{array}{l}\text { Long hyphae, fragmentation } \\
\text { of aerial mycelium }\end{array}$ & III & NT & MK-9 & $3 d$ & $\mathrm{C}$ \\
\hline Streptoalloteichus & $\begin{array}{l}\text { Long hyphae and sporangia, } \\
\text { motile spore }\end{array}$ & III & Acetyl & $\mathrm{MK}-10\left(\mathrm{H}_{4}, \mathrm{H}_{6}\right)$ & $3 \mathrm{e}$ & $\mathrm{E}$ \\
\hline Saccharothrix & $\begin{array}{l}\text { Spore chain, fragmentation, } \\
\text { sporulation ('zig-zag' } \\
\text { morphology) }\end{array}$ & III & ND & MK-10( $\left.\mathrm{H}_{4}\right), 9\left(\mathrm{H}_{4}\right)$ & $3 f$ & $C(E)$ \\
\hline Amycolatopsis & Long spore chain & IV & Acetyl & MK-9 $\left(\mathrm{H}_{2}\right), 8\left(\mathrm{H}_{4}\right)$ & $3 f$ & A \\
\hline Pseudonocardia & Long spore chain & IV & Acetyl & $\mathrm{MK}-8\left(\mathrm{H}_{2}, \mathrm{H}_{4}\right)$ & 2 & A \\
\hline Actinokineospora & $\begin{array}{l}\text { Long spore chain, motile } \\
\text { spore }\end{array}$ & IV & Acetyl & MK-9 $\left(\mathrm{H}_{4}\right)$ & $2 d$ & A \\
\hline Kutzneria & Sporangium & III & Acetyl & $\begin{array}{l}\operatorname{MK}-9\left(\mathrm{H}_{4}, \mathrm{H}_{2}, \mathrm{H}_{6}\right), 8\left(\mathrm{H}_{4}\right) \\
10\left(\mathrm{H}_{4}\right)\end{array}$ & $3 \mathrm{c}$ & $\mathrm{E}$ \\
\hline Actinosynnema & $\begin{array}{l}\text { Spore chain, synnemata, } \\
\text { motile spore }\end{array}$ & III & Acetyl & MK-9( $\left.\mathrm{H}_{4}\right), 10\left(\mathrm{H}_{4}\right)$ & $3 f$ & $\mathrm{C}$ \\
\hline Kibdelosporangium & Sporangium-like structure & IV & Acetyl & $\begin{array}{l}\operatorname{MK}-9\left(\mathrm{H}_{2}, \mathrm{H}_{4}, \mathrm{H}_{6}\right), 8\left(\mathrm{H}_{4},\right. \\
\left.\mathrm{H}_{6}\right)\end{array}$ & $3 \mathrm{c}$ & A (B) \\
\hline Saccharopolyspora & Beadlike spore chain & IV & Acetyl & $\mathrm{MK}-9\left(\mathrm{H}_{4}\right)$ & $2 \mathrm{c}$ & A \\
\hline Saccharomonospora & $\begin{array}{l}\text { Single spore on aerial } \\
\text { mycelium }\end{array}$ & IV & ND & MK-9 $\left(\mathrm{H}_{4}\right)$ & $2 \mathrm{a}$ & A \\
\hline Actinopolyspora & Long spore chain & IV & ND & MK-9(H $\left.\mathrm{H}_{4}\right), 10\left(\mathrm{H}_{4}\right)$ & $2 \mathrm{c}$ & A \\
\hline Thermocrispum & $\begin{array}{l}\text { Pseudosporangium, long } \\
\text { chain, fragmentation }\end{array}$ & III & ND & $\mathrm{MK}-9\left(\mathrm{H}_{4}\right)$ & $3 \mathrm{f}$ & $\mathrm{C}(\mathrm{A})$ \\
\hline Actinobispora & $\begin{array}{l}\text { Long hyphae, single spore or } \\
\text { pair of spores on aerial } \\
\text { mycelium }\end{array}$ & IV & ND & $\mathrm{MK}-7\left(\mathrm{H}_{2}\right), 9\left(\mathrm{H}_{2}\right)$ & ND & A \\
\hline
\end{tabular}

* According to the classification of Lechevalier \& Lechevalier (1970). All organisms have the meso-diaminopimelic acid isomer. $\uparrow$ According to the classification of Kroppenstedt (1985).

$\$$ According to the classification of Lechevalier \& Lechevalier (1970).

Academia Sinica as strain AS $4.1159^{\mathrm{T}}$ and in the Japan Collection of Microorganisms as strain JCM $6095^{\mathrm{T}}$.

\section{Description of Actinoalloteichus gen. nov.}

Actinoalloteichus (Ac.ti.no.al.lo.tei'chus. Gr. n. actis, actinos a ray, beam; Gr. adj. allos different; Gr. n. teichos wall; M.L. masc. n. Actinoalloteichus actinomycete with a different wall).

Gram-positive, non-acid-fast, aerobic organisms with branching hyphae. Non-fragmentary substrate mycelia are present. Aerial mycelia with straight spore chains aggregate. The aerial and substrate mycelia tend to fragment. Strictly aerobic. Good growth occurs at $20-37^{\circ} \mathrm{C}$. The organism shows good growth on yeast extract/malt extract agar and oatmeal agar. Cell walls contain glutamic acid, glucosamine, alanine and meso-diaminopimelic acid. The wall chemotype is III, according to Lechevalier \& Lechevalier (1970), and the peptidoglycan type is suggested to be $\mathrm{A} 1 \gamma$ according to
Schleifer \& Kandler (1972). Ribose, mannose, galactose and glucose are detected in whole-cell sugars. Anteiso- $\mathrm{C}_{17: 0}$, iso- $\mathrm{C}_{15: 0}$, iso- $\mathrm{C}_{16: 0}$ and anteiso- $\mathrm{C}_{15: 0}$ are present as major cellular fatty acids. The $\mathrm{G}+\mathrm{C}$ content of the DNA is $73 \mathrm{~mol} \%$. The major menaquinone is MK-9 $\left(\mathrm{H}_{4}\right)$ and small amounts of MK- $8\left(\mathrm{H}_{4}\right)$ and $9\left(\mathrm{H}_{2}\right)$ are also present. Phosphatidylethanolamine and phosphatidylmonomethylethanolamine are present as diagnostic phospholipids. The acyl type of the cell wall polysaccharides is acetyl. The type species is Actinoalloteichus cyanogriseus.

\section{Description of Actinoalloteichus cyanogriseus sp. nov.}

Actinoalloteichus cyanogriseus (cya.no.gri'se.us. L. adj. cyaneus deep blue; M.L. adj. griseus grey; M.L. adj. cyanogriseus blue-grey).

Morphological, chemotaxonomic and general characteristics are as given above for the genus. The veg- 
etative mycelia are brown to grey in colour and the aerial mycelia are blue to grey. A black soluble pigment is produced on yeast extract/malt extract agar. Decomposition of casein and urea, growth in Sabouraud dextrose broth and MacConkey agar, hydrolysis of aesculin and hippurate, utilization of sodium citrate, sodium succinate and calcium malate, gelatin liquefaction and reduction of nitrate are all negative. Glucose, maltose, xylose, mannitol, rhamnose, mannose and sorbitol are utilized, but inositol, fructose and raffinose are not. No growth at 15 or $45^{\circ} \mathrm{C}$. The $\mathrm{G}+\mathrm{C}$ content of the DNA is $73 \mathrm{~mol} \%$. The type strain is IFO $14455^{\mathrm{T}}$ $\left(=\right.$ AS $\left.4.1159^{\mathrm{T}}=\mathrm{JCM} 6095^{\mathrm{T}}\right)$. The habitat is cultivated soil.

\section{ACKNOWLEDGEMENTS}

We thank Takashi Itoh for reading of this manuscript and Yayoi Yamaguchi for technical assistance.

\section{REFERENCES}

Felsenstein, J. (1985). Confidence limits on phylogenies: an approach using the bootstrap. Evolution 39, 783-791.

Gordon, R. E., Barnett, D. A., Handerhan, J. E. \& Pang, C. H. (1974). Nocardia coeliaca, Nocardia autotrophica, and the nocardin strain. Int J Syst Bacteriol 24, 54-63.

Hasegawa, T., Lechevalier, M. P. \& Lechevalier, H. A. (1978). New genus of the Actinomycetales: Actinosynnema gen. nov. Int $J$ Syst Bacteriol 28, 304-310.

Hayakawa, M. \& Nonomura, H. (1987). Humic acid-vitamin agar, a new medium for selective isolation of soil actinomycetes. $J$ Ferment Technol 65, 501-509.

Itoh, T., Kudo, T. \& Seino, A. (1987). Chemotaxonomic studies on new genera of actinomycetes proposed in Chinese papers. Actinomycetologica 1, 43-59.

Kimura, M. (1980). A simple method for estimating evolutionary rates of base substitutions through comparative studies of nucleotide sequences. J Mol Evol 16, 111-120.

Korn-Wendisch, F., Rainey, F., Kroppenstedt, R. M., Kempf, A., Majazza, A., Kutzner, H. J. \& Stackebrandt, E. (1995). Thermocrispum gen. nov., a new genus of the order Actinomycetales, and description of Thermocrispum municipale sp. nov. and Thermocrispum agreste sp. nov. Int J Syst Bacteriol 45, 67-77.

Kroppenstedt, R. M. (1985). Fatty acid and menaquinone analysis of actinomycetes and related organisms. In Chemical Methods in Bacterial Systematics, pp. 173-199. Edited by M. Goodfellow \& D. E. Minnikin. London: Academic Press.

Labeda, D. P., Testa, R. T., Lechevalier, M. P. \& Lechevalier, H. A. (1984). Saccharothrix: a new genus of Actinomycetales related to Nocardiopsis. Int J Syst Bacteriol 34, 426-431.
Lechevalier, M. P. \& Lechevalier, H. A. (1970). Chemical composition as a criterion in the classification of aerobic actinomycetes. Int J Syst Bacteriol 20, 435-443.

Liu, Z., Zhang, Y. \& Yan, X. (1984). A new genus of the order Actinomycetales. Acta Microbiol Sin 24, 295-298.

Pernodet, J.-L., Borccard, F., Alegre, M.-T., Gargnat, J. \& Guérineau, M. (1989). Organization and nucleotide sequence analysis of ribosomal RNA gene cluster from Streptomyces ambofaciens. Gene 79, 33-46.

Perrière, G. \& Gouy, M. (1996). WWW-Query: an on-line retrieval system for biological sequence banks. Biochimie 78, 364-369.

Rayner, R. W. (1970). A Mycological Colour Chart. Kew: Commonwealth Mycological Institute/British Mycological Society.

Saitou, N. \& Nei, M. (1987). The neighbor-joining method: a new method for reconstructing phylogenetic trees. Mol Biol Evol 4, 406-425.

Schleifer, K. H. \& Kandler, O. (1972). Peptidoglycan types of bacterial cell walls and their taxonomic implications. Bacteriol Rev 36, 407-477.

Stackebrandt, E., Kroppenstedt, R. M., Jahnke, K. D., Kemmerling, C. \& Gürtler, H. (1994). Transfer of Streptosporangium viridogriseum (Okuda et al. 1996), Streptosporangium viridogriseum subsp. kofuense (Nonomura and Ohara 1969) and Streptosporangium albidum (Furumai et al. 1968) to Kutzneria gen. nov. as Kutzneria viridogriseria comb. nov., Kutzneria kofuensis comb. nov., and Kutzneria albida comb. nov., and emendation of the genus Streptosporangium. Int $J$ Syst Bacteriol 44, 265-269.

Stackebrandt, E., Rainey, F. A. \& Ward-Rainey, N. L. (1997). Proposal for a new hierarchic classification system, Actinobacteria classis nov. Int J Syst Bacteriol 47, 479-491.

Tamura, T. \& Hatano, K. (1998). Phylogenetic analyses on the strains belonging to invalidated genera of the order Actinomycetales. Actinomycetologica 12, 15-28.

Tamura, T., Hayakawa, M. \& Hatano, K. (1998). A new genus of the order Actinomycetales, Cryptosporangium gen. nov., with descriptions of Cryptosporagium aridum sp. nov. and Cryptosporangium yamanashiensis sp. nov. Int J Syst Bacteriol 48, 995-1005.

Thompson, J. D., Higgins, D. G. \& Gibson, T. J. (1994). CLUSTAL $\mathrm{W}$ : improving the sensitivity of progressive multiple sequence alignment through sequence weighting, position-specific gap penalties and weight matrix choice. Nucleic Acids Res 22, 4673-4680.

Tomita, K., Nakakita, Y., Hoshino, Y., Numata, K. \& Kawaguchi, H. (1987). New genus of the Actinomycetales: Streptoalloteichus hindustanus gen. nov., nom. rev.; sp. nov., nom. rev. Int J Syst Bacteriol 37, 211-213.

Yokota, A., Tamura, T., Hasegawa, T. \& Huang, L. H. (1993). Catenuloplanes japonicus gen. nov., sp. nov., nom. rev., a new genus of the order Actinomycetales. Int J Syst Bacteriol 43, 805-812. 